coach. A current of about 1,500 amp. up to 8 volts is injected for pre-energizing the rails to ensure uniformity of molecular arrangement prior to the introduction of the detecting current just in front of the two pairs of searching coils. This precaution is necessary because running rails are generally magnetized by the normal effect of the earth's field, augmented by vibration due to the pounding of passing train wheels.

The magnetic poles strongly formed in this way are of two kinds; the effects of the superficial ones on the surface of the rail can be avoided by the use of suitable brush gear for conveying the test current to the rails, while those within the railhead can be overcome by raising the detective current density to 275 amp. per sq. in., which means feeding 4,000 amp. to each rail at up to 4 volts. The testing currents are furnished by a petrol engine with gear-box and multiple belt pulley which drives the main current $(8,000 \mathrm{amp}$ ) and auxiliary (pre-energizing) generators and a 200 -volt exciter mounted together in the car. The recording tape moves at $0.025 \mathrm{in}$. per $\mathrm{ft}$. of car travel; the recording car travels at seven miles per hour when fault detecting. It is reported that in seven months this year 597,000 miles of track, tested in this way, revealed 304,000 defective rails.

\section{Movable Electric Generating Stations}

The Commissariat of the Building Industry of the U.S.S.R. is constructing 1,000 movable electric generating stations for use in timber camps and on railway construction jobs. The movable generating stations will be of various capacities, beginning with the smallest, of $2.5 \mathrm{kw}$, which will be used by railway maintenance men. Generators of this capacity will be installed on hand-carts and moved about from place to place as required. Electric generating stations of $30 \mathrm{kw}$. capacity will be fitted on the running-boards of automobiles and worked by the motor engine. A novel feature of the electric power stations of $50 \mathrm{kw}$. capacity will be a gas generator, instead of the ordinary Diesel engine, which will effect a considerable saving of fuel.

\section{New Seismographs for Boulder Dam}

AN ambitious, though necessary, seismological programme is being undertaken in the neighbourhood of the Great Boulder Dam (Earthquake Notes, 22, Nos. 1 and 2, September 1940). A Wood-Anderson seismograph has been operating for several years at Boulder City, and two Neumann-Labarre vibration meters are temporarily installed at Overton, Nevada. The seismograph buildings at Pierce Ferry on Lake Mead are almost ready to house the temporary Coast and Geodetic Survey vibration meters. The construction of permanent Benioff instruments recording on $35-\mathrm{mm}$. motion picture film for all three stations is nearing completion. Four records, two horizontal, one vertical and one 'time record', will be made simultaneously on one drum. The 'time record' will be a film on which radio time signals will be recorded at regutar intervals several times each day in addition to the regular chronometer time marks. Through the use of a reading microscope with two-way micrometer control, it will be possible to read time from the record to the nearest hundredth of a second and to measure amplitude to corresponding precision. Another feature of the seismographs is a second vertical seismometer used to control relays for intensifying the recording light at times of recording strong seismic disturbances.

\section{Earthquake in Chile}

ON the basis of instrumental reports from fourteen seismographic observatories, the United States Coast and Geodetic Survey, in co-operation with Science Service and the Jesuit Seismological Association, has determined the epicentre of the earthquake of October 11, 1940, to be provisionally at latitude $45^{\circ} \mathrm{S}$., longitude $73^{\circ} \mathrm{W}$. This is on the mainland of Chile opposite the Chanos Archipelago and north of Taitao Peninsula. It has been the scene of many small earthquakes and earth tremors in the past.

\section{Announcements}

Prof. Hugo Iltis, formerly director of the Mendel Museum in Brno, has been appointed professor of biology in Mary Washington College, Fredericksburg, Virginia.

Prof. Th. Dobzhansky, formerly professor of genetics in the California Institute of Technology, Pasadena, has been appointed professor of zoology in Columbia University, New York.

DR. A. C. SмIтH, formerly associate curator of the Herbarium, New York Botanical Garden, has been appointed curator of the Herbarium of the Arnold Arboretum, of Harvard University.

THE following appointments in the Colonial Service have recently been made: J. E. Hardy, chief plant protection officer, Palestine; J. K. H. Wilde, veterinary research officer, Tanganyika.

At a Congregation of the Senate of the University of Cambridge on December 9, degrees of M.A. honoris causa were conferred on Prof. A. M. Carr-Saunders, director of the London School of Economics and Political Science; Prof. F. L. Hopwood, professor of physics in the University of London (St. Bartholomew's Hospital Medical College); and Prof. A. E. Richardson, professor of architecture in University College, London.

The British Museum (Natural History) has recently published three additions to the series of "Economic Leaflets". These are No. 4, "Psocids, Book Lice, Dust Lice, etc." ; No. 5, "Crickets" ; and No. 6, "Plaster Beetles". Each type of insect dealt with is clearly illustrated and an account is given of its habits, the injuries that it may cause and the best means of controlling it. The leaflets are sold at the British Museum, Cromwell Road, London, S.W.7, price $1 d$. each for Nos. 5 and 6 , and $\frac{1}{2} d$. for No. 4 . 